\title{
Financial Resource Mobilisation Strategies and Sustainability of Non-Governmental Organisations (NGOs): Evidence from Nigeria
}

Susannah Fisayo Otaru* https://orcid.org/0000-0001-7012-8112

Mercy Modupe Adeyeye** https://orcid.org/0000-0001-9644-9811

Ademola Samuel Sajuyigbe ${ }^{* * \star}$ https://orcid.org/0000-0001-6120-6908

${ }^{*}$ Federal University of Technology, Minna, Nigeria. Email: otarusuzy65@yahoo.com

${ }^{* *}$ Federal University of Technology, Minna, Nigeria; Landmark University, Omu-Aran, Nigeria; SDG 1: No poverty research group. Email: memoade4real@yahoo.com

***Landmark University, Omu-Aran, Nigeria; SDG 1: No poverty research group. Email: sajuyigbeademola@yahoo.com

Background. The challenge facing NGOs in most developing countries is the need to emerge as valuable forces that affect development in order to improve the living conditions of the people in several communities. Funding is necessary for the survival and development of these NGOs. Research aims: This study, therefore, sought to find out the effect of financial resource mobilisation strategies on the sustainability of NGOs in Nigeria, with particular reference to the Minna metropolis.

Research aims. The purposive sampling technique was used to select 118 staff from 50 NGOs as a sample size for the study. Three alternative hypotheses were raised to be tested at $P<.05$ and a structured questionnaire was adopted for data collection. The data were analysed using descriptive statistics, Pearson Correlation, and the Ordinary Least Square method of estimation. Methodology. The result revealed the existence of a statistically significant and positive relationship between private contributions and the sustainability of NGOs, a positive but insignificant relationship between commercial activities and sustainability of NGOs, and an inverse relationship between government funding and sustainability of NGOs.

Findings. The study established that private contributions affect the sustainability of NGOs to a very large extent; government funding does not improve the sustainability of NGOs, and commercial activities do not have a significant impact on the sustainability of NGOs. Consequently, the study recommended that management and staff of NGOs should create more awareness about their operations in order to attract better contributions from private individuals and organisations.

Keywords

NGOs, resource mobilisation, financial resources, social needs, sustainability

\section{Introduction}

Most communities in developing countries have persisting and multiplying social needs and problems, creating a growing demand for new non-governmental organisations (NGOs) and new services from existing NGOs (Ngeh, 2013). The failure of traditional development initiatives of the government and international organisations to achieve the objectives of solving societal problems prompted the emergence of NGOs as interventionist organisations for the unsatisfied in the society (Ngeh, 2013; Utuk, 2014; Odunola \& Odunsi, 2017). The result has been a significant emphasis on the concept of social entrepreneurship globally with the goal of effecting positive social change (Di Zhang \& Swanson, 2013; Khieng \& Dahles, 2015). Social entrepreneurship is about applying practical, innovative, and sustainable approaches to benefit society in general, especially those who are marginalised and poor (Adeyeye, 2016). Specifically, social values are derived from entrepreneurial activities that seek to address problems related to people and society through non-profit organisations, mostly known as non-governmental organisations (NGOs) (Lewis, 2010; Di Zhang \& Swanson, 2013; Adeyeye, 2016).

+ Corresponding author 
Despite the important roles NGOs play in the development process, they face a number of challenges that raise concerns about their sustainability (Kearns et al., 2014; Mbuya \& Osodo, 2018; Shava, 2019). The sustainability of NGOs is an increasingly prominent theme in the trending multidisciplinary field of social entrepreneurship (Khieng \& Dahles, 2015). It is a key component of NGOs, in that it allows them to provide larger and more complex services related to their mission (Morris et al., 2012; Adeyeye, 2016). Where they are active, NGOs act as interventionists because the present state of the economy and the increasing demands of citizens have hindered the government from being the sole provider of goods and services (Dimelu et al., 2013; Shava, 2019). The vast developmental activities undertaken by NGOs and their roles in meeting social needs require continuous and stable availability of financial resources (Kangiri, 2015). For NGOs to realise their potential to contribute and to efficiently manage their activities, it is essential for them to be sustainable. Although donors are the major sources of funding for NGOs, the level of donor contributions has steadily declined due to several factors, such as global environmental issues (Batti, 2014). This has affected the operations of several NGOs and has led many of them to cease operations, often due to lack of sustainable funding (Svidroňová, 2014; Valentinov \& Vaceková, 2015).

The search for funding is, therefore, necessary for the survival and development of these NGOs. This is because NGOs, like any other organisation, require a substantial amount of funds and other resources to successfully carry out their programmes and activities. There have been limited studies on resource mobilisation strategies and sustainability of NGOs across the globe within the past few years. The few available studies were conducted in Cambodia (Khieng, 2014), in South Africa (Abdullahi \& Baba, 2016), in Nigeria (Adeyeye, 2016), in Kenya (Koech, 2017), and in Ghana (Benedict \& Richard, 2020) and only focused on the role NGOs play in the development of the economy. To the best of the researchers' knowledge, no or few studies have conducted a study on financial resource mobilisation strategies and sustainability of NGOs in Africa, especially Nigeria. The above analysis highlights the gap that this study seeks to fill. In view of the above, it is therefore imperative to conduct a study on financial resource mobilisation strategies and sustainability of NGOs in Nigeria, with particular reference to Minna, Niger State.

\section{Research Questions}

The following research questions are germane to this research:

- To what extent do private contributions have a significant effect on sustainability of NGOs?

- To what extent does government funding have a significant effect on sustainability of NGOs?

- To what extent do commercial activities have a significant effect on sustainability of NGOs?

\section{Review of Related Literature and Formulation of Hypotheses}

\section{Concept of Sustainability}

Sustainability is a new and evolutionary concept, and it applies in various fields. The main reason to focus on environmental concerns is that resources are now depleted to the point of affecting future generations. Sustainability means finding a strategy to increase true and real costs for fee-dependent structures and assets, recognising that sustainability requires corporate growth and profitability but that corporations in particular need to achieve corporate social aspirations that include environmental protection, social justice, and economic development. Sustainability is a long-standing corporate premise referring to a concept of international accountability comprising economic, social, and environmental factors while protecting the interests of all stakeholders. Organisational stability refers to the firm's ability to produce economic, social, and environmental performance simultaneously. According to Bansal (2001), businesses that fail to adhere to the principles of sustainability "will almost certainly face extinction." Sustainable development in the field of governance has been studied, and a number of benefits have been recognised, including improved food quality (Adeyeye, 2016), competitiveness (Kangiri, 2015), and responsibility (Haywood et al., 2013). However, Svidroňová (2014) sees flexibility as how businesses can deal with the risks of wealth inequality in the twenty-first century, increasingly associated with the social risks of indifference and violence; growing scarcity of natural resources; excessive cost of fossil fuels; labour disputes; community responses to human rights violations; and lack of a competent, technologically savvy workforce ready to take on jobs that can lift entire groups out of poverty.

\section{Private contributions and sustainability of NGOs}

The traditional, dominant, and most common form of NGO financing is private contributions (Khieng, 2014; Kangiri, 2015). Private contributions represent funds that NGOs gather for efficient performance and implementation of their programme and operational activities (Khieng, 2014; Abdullahi and Baba, 2016). This funding strategy is very useful to NGOs' work, primarily because it 
mobilises funds from different sources/donors, encourages engagement with different problems, and proposes activities that considerably contribute to improving and promoting the development of the community in which they operate (Khieng \& Dahles, 2015). Typically, private contributions are valued by NGOs as they not only provide income but also indicate support for the organisation's mission among constituents, thus representing legitimacy (Khieng, 2014). Unerman and O'Dwyer (2010) indicated that funding from private contributors for many NGOs is significantly higher compared to funds from governmental sources. Herzer \& Nunnenkamp (2013) revealed that philanthropic donations are an important source of new and expanded resources for NGOs, especially smaller and grassroots organisations. However, funding from private contributions to NGOs is usually unpredictable and unstable and comes with different issues that can negatively affect the organisation's goals and missions (Herzer \& Nunnenkamp, 2013; Khieng, 2014; Ali \& Kilika, 2016). Khieng (2014) emphasised that some NGOs may have to adjust or modify their goals/ programme priorities to fit or satisfy the requirements of individual donors, causing a goal displacement effect. Revenue volatility is also a constraint that can be associated with dependence on private contributions (Batti, 2014; Karanga \& Kuruti, 2014).

Based on the conflicting empirical results, the following hypothesis emerged:

\section{$\mathbf{H}_{\mathbf{1}}$ : Private contributions have a significant effect on NGOs' sustainability}

\section{Government funding and sustainability of NGOs}

Government funding constitutes an important funding strategy for NGOs (Herzer \& Nunnenkamp, 2013; Kangiri, 2015; Khieng, 2014; Liu et al., 2015; Stremfelj et al., 2020). Khieng (2014) described it as "national budget allocation or development assistance from multilateral and bilateral donors, which is channelled through government ministries or sub-national government to NGOs." The second largest stable source, it is also the predominant source of revenue internationally, especially for NGOs engaged in health and social service activities in most countries (Kangiri, 2015). Besel et al. (2011) viewed government funding as the most dependable funding source for NGOs' survival. Many NGOs depend on government funding (Stremfelj et al., 2020), and this financial dependence on public money has increased in recent decades as more government-funded services are delivered through grants and contracts (Kerlin \& Pollak, 2011; Ali \& Kilika, 2016). Government funds have certain advantages because they can be used for a variety of activities, whether joint activities or events (Herzer \& Nunnenkamp, 2013; Batti, 2014).

NGOs capitalise on the government's steady financial support to improve the efficiency of the service delivery process mainly through the achievement of scale through large blocks of government support (Herzer \& Nunnenkamp, 2013). Some researchers, such as Kerlin and Pollak (2011) and Khieng (2014) opine that the flow of government funds into NGOs allows them to expand their operations substantially and enables them to achieve greater levels of operational efficiency and improved effectiveness. Spooner and Dadich (2010) while identifying the problems of government funding for NGOs states that problems of government funding are not only about shortfall but include the impacts of the funding contracts culture on how NGOs operate, the fading capacity of NGOs to contribute to social capital or public policy, their decreasing ability to collaborate with other NGOs, and their increasing organisational fragility. Dependence on government funding can lead to NGOs compromising their missions and autonomy as well as goal displacement, institutional isomorphism, and changes in the internal processes (Khieng, 2014; Mitchell, 2014). Another major limitation of government funding is corruption, where a certain percentage of allotted funds are released to NGOs, but the NGOs must account for the full amount (Herzer \& Nunnenkamp, 2013). Mitchell (2014) concluded that depending on government funding relates specifically to increased revenue stability, but it may also lead toward goal displacement and institutional isomorphism. Thus, the following hypothesis is formulated:

$\mathbf{H}_{2}$ : Government funding has a significant effect on NGOs' sustainability

\section{Commercial activities and sustainability of NGOs}

NGOs' commercial activities include membership fees, sale of services and products, use of intangible and tangible assets, and use of investment appreciation (Vaceková and Svidroňová, 2014). Vaceková and Svidroňová (2014) also added that "commercial income is income from investment activity or yield of capital which also applies to the restructuring of assets and includes the sale of assets and the associated effects of financing, such as the sale of buildings and real estate." Commercial incomes are, on the contrary, incomes from activities not related to the mission of an NGO but that are carried out in order to fill up financial deficiencies (Mitchell, 2014; Vaceková \& Svidroňová, 2014). NGOs adopt commercial activities as another form of resource mobilisation strategy to tap new resources and sustain the organisation (Gras \& Mendoza-Abarca, 2014). Moreover, profit from commercial transactions enables NGOs to maintain their daily operation, continually provide public services to satisfy diverse social needs, and safeguard the public mission statement of the organisations (Khieng \& Dahles, 2015).

Commercial activities as compared to the other forms of funding mobilisation of NGOs helps to minimise the likelihood of goal displacement and promotes the flexibility and autonomy of the organisation (Khieng, 2014). Another reason that makes the 
addition of commercial activities attractive among NGOs is the benefit of self-sufficiency (Gras \& Mendoza-Abarca, 2014). One of the additional benefits for many NGOs engaging in some forms of commercial activities related to their mission is the flexibility of revenues earned (Valentinov \& Vaceková, 2015). Despite the positive effects of this form of mobilisation strategy, it has its own limitation, one of which is that it generates social and ethical dilemmas, competition with private sectors, and loss of priority of achieving the organisation's mission (Khieng \& Dahles, 2015). By engaging in commercial activities, NGOs are exposed to commercial market risk and also to the risk of goal displacement, insolvency, programme disruption, and loss of tax exemption (Gras \& Mendoza-Abarca, 2014). More so, researchers have argued that having commercial activities can distract NGOs from their social missions and compromise their ability to create social value (Gras \& Mendoza-Abarca, 2014; Khieng \& Dahles, 2015; Svidroňová, 2014). Thus, the following hypothesis is formulated:

$\mathbf{H}_{3}$ : Commercial activities have a significant effect on NGOs' sustainability

\section{Methodology}

This study employed a descriptive survey research design because it is a means of gathering information about the characteristics, actions, or opinions of a large group of people. The study was conducted in Minna, the capital of Niger State. The choice of this state is based on the fact that it has the highest number of NGOs in the country due to the high rate of almajiris, child labour, and under-age marriage (Adeyeye, 2016). The purposive sampling technique was used to select four principal officers (administration officer, accounting officer, public relation officer, and mobilisation officer) from 50 NGOs in Minna metropolis, totalling 200 participants as a sample size for the study. These principal officers were selected because they are in the right positions to provide the required information. The questionnaires were personally administered by the researchers to the participants, based on a drop and pick after a one-day basis. This method of administration was preferred because it had a higher response rate. The process was effective and productive but not rapid, as the data was collected over four weeks. However, 118 copies of the questionnaire were retrieved. To ascertain the validity and reliability of the instrument, face and content validity of the questionnaire was carried out in the School of Entrepreneurship and Management Technology, Federal University of Technology, Minna, while the test-retest method of reliability was used when carrying out the pilot study in Minna among 20 NGO staff, with a Cronbach's Alpha value of 0.89. This indicates that the accuracy level of the questionnaires was up to 89 percent. Data analysis was performed with the aid of descriptive statistics, Pearson Correlation, and the Ordinary Least Square method of estimation.

\section{Model Specification}

The study adopted the Linear Regression Model for the analysis of the data collected. This model is one of the statistical tools used for analysing data quantitatively. The regression analysis was conducted to show the multiple effects of the relationship between financial resource mobilisation strategies and sustainability.

This model is stated as follows:

$$
\begin{aligned}
& \mathrm{Y}=\mathrm{f}\left(\mathrm{X}_{1}, \mathrm{X}_{2}, \ldots \ldots \ldots \ldots \ldots . . . \mathrm{X}_{\mathrm{n}}\right) \\
& Y=\beta_{0}+\beta_{1} X_{1}+\beta_{2} X_{2}+\beta_{3} X_{3}
\end{aligned}
$$

Where $\quad \mathrm{Y}=$ Dependent Variable of the study

$$
\mathrm{X}_{1} \ldots . . \mathrm{X}_{\mathrm{n}}=\text { Independent variable of the study }
$$

Substituting the variable of this current study into equation 1 above, we have:

$S T Y=f(P V C, G V F, C O A)$

Where, $\quad$ STY $=$ Sustainability

PVC $=$ Private contributions

GVF $=$ Government funding

$\mathrm{COA}=$ Commercial activities

Thus, the econometric model is as stated below:

$\mathrm{STY}=\beta_{0}+\beta_{1} \mathrm{PVC}+\beta_{2} \mathrm{GVC}+\beta_{3} \mathrm{COA}+\dot{\varepsilon}$ 


\section{Results and Discussion}

Table 1 indicates that the data are normally distributed. Looking closely at the mean values of the variables, it is clear that there are no outliers. Also, the skewness values for the variables, which all approximate to ' 0 ' and is the value for normal skewness, and the kurtosis values of approximately 3', all show that the data were normally distributed. The descriptive statistic results in Table 1 indicate that mean values of sustainability, private contribution, government contribution, and commercial activities are $7,3.174,2.116$, and 2.560 , respectively. The common feature of these variables is that they all have positive mean values. This shows that each of the variables displays increasing tendency throughout the sampling period. The average value of sustainability is 7.0 , which implies that the proportion of sustainability of NGOs in Minna is very low. Thus, more attention should be given to measures that will improve the sustainability of NGO operations in the long run. The average value of the private contribution is approximately 3.174. This average value is high, however; NGOs need to create more awareness about their operations in order to attract better contributions from private individuals and organisations.

The average values of the government contribution and commercial activities are 2.116 and 2.560 , respectively. Though these values are positive, they are lower than the average contribution from private sources to NGOs' sustainability. This implies that private contribution supports the survival of NGOs more than government contribution and commercial activities. Therefore, to enhance NGOs' sustainability, the government needs to step up its contribution in view of the vital services rendered by these NGOs. Also, as suggested by Vaceková and Svidroňová (2014) and Mbuya and Osodo (2018), NGOs need to be more innovative by investing more in commercial activities that could enhance their survival. The result above also shows that except for sustainability, which shows a high degree of variation with a standard deviation (SD) value of 17, other variables have remained fairly stable in their contribution. This high volatility in the sustainability of NGOs in Nigeria is worrisome as it does not bode well for their continuous existence.

Table 2 presents the correlation result between the dependent variable (sustainability) and the independent variables. The dependent variable, which correlated with the independent variables, are private contributions $(r=0.292)$, which are significantly correlated at $P<0.05$, government funding ( $r=-0.027$ ), with a negative significant relationship at $P<0.05$, and commercial activities $(r=0.009)$, which has no positive significant relationship at $P<0.05$. This means that the inter-variable correlations between the independent variables were not strong enough to affect the relationship with the dependent variable. The result also indicated that as private contributions and commercial activities increase so does the sustainability of NGOs, while the increase in government funding will lead to a decrease in the sustainability of NGOs. This suggests that private contributions are more closely related to the sustainability of NGOs as compared to government funding and commercial activities.

\section{Presentation of Collinearity Statistic Result}

This test was carried out to ascertain the presence or absence of multi-collinearity among the independent variable. The result of the test is presented in Table 3.

Table 3 shows the absence of multi-collinearity as it indicates that VIF values are below 10 while tolerance levels are all above 0.10. VIF lower than 10 and tolerance level higher than 0.10 are indicators of the absence of multicollinearity (Hair Jr. et al., 2015). Similarly, the Durbin-Watson statistic value of 1.360 indicates the presence of autocorrelation between the regress and the regressors.

Table 4 shows regression analysis between sustainability and financial resource mobilisation strategies. This shows that there is a significant relationship between the independent and the dependent variables. The result shows that the variables

Table 1. Descriptive Statistics Result

\begin{tabular}{|c|c|c|c|c|c|c|c|}
\hline & $\begin{array}{l}\mathbf{N} \\
\text { Statistic }\end{array}$ & $\begin{array}{l}\text { Minimum } \\
\text { Statistic }\end{array}$ & $\begin{array}{l}\text { Maximum } \\
\text { Statistic }\end{array}$ & $\begin{array}{l}\text { Mean } \\
\text { Statistic }\end{array}$ & $\begin{array}{l}\text { Std. Deviation } \\
\text { Statistic }\end{array}$ & $\begin{array}{l}\text { Skewness } \\
\text { Statistic }\end{array}$ & $\begin{array}{l}\text { Kurtosis } \\
\text { Statistic }\end{array}$ \\
\hline Sty & 118 & .0 & 86.0 & 7.000 & 17.1419 & 0.000 & 3.035 \\
\hline PVC & 118 & .9 & 5.9 & 3.174 & .7503 & 0.004 & 3.163 \\
\hline GVF & 118 & 1.0 & 4.2 & 2.116 & .6064 & 0.000 & 3.127 \\
\hline $\mathrm{COA}$ & 118 & 1.0 & 4.3 & 2.560 & .9756 & 0.022 & 2.930 \\
\hline
\end{tabular}

Valid N (listwise) 118

Authors' Computation 
Table 2. Summary of Correlations

\begin{tabular}{lc}
\hline VARIABLES & COEFFICIENTS \\
\hline Sustainability & 1 \\
Private contributions & .292 \\
Government funding & -.027 \\
Commercial activities & .009 \\
Correlation is significant at 0.05 level (2-tailed) & \\
\hline
\end{tabular}

Source: Authors' computation.

are significantly related at $\mathrm{r}-29.1 \%(\mathrm{P}<0.05)$. This indicates that private contributions, government funding, and commercial activities accounted for $8.5 \%$ of the variations in the sustainability of NGOs while other variables not included in the model account for $91.5 \%$. The $\mathrm{F}$. values of 3.511 in the result are significant at 0.018 , and with a P-value that is less than $5 \%$, the indication is that the model is well fitted. Further, the result indicates that, at a 0.05 level of significance, there is a significant positive effect of private contribution on the sustainability of NGOs. With a coefficient of 0.291 and a p-value of 0.002 , it implies that a unit increase in private contribution, holding other predictors fixed, will produce a 0.29 units increase in the sustainability of NGOs. Also, the government contribution impacts negatively NGOs sustainability with a coefficient of -0.009 and a P-value of 0.920 . The result indicates that a unit increase in government contribution to NGOs significantly decreases sustainability by -0.009 units. Lastly, the result in Table 4 also indicates that commercial activities have a positive but insignificant effect on the sustainability of NGOs. This is shown by a coefficient value of 0.041 with a P-value of 0.647 . The statistical implication of this result is that at 0.05 level of significance, a unit increase in commercial activities by NGOs significantly enhances their sustainability by just 0.041 units. The findings by Besel et al. (2011), Herzer and Nunnenkamp (2013), Khieng (2014), Abdullahi and Baba (2016), and Ali and Kilika (2016) lend credence to this, in that their studies empirically established a positive correlation between private donor funding and NGO sustainability. This is in contrast to Kerlin and Pollak (2011) who discovered that diversification of financial sources is one of the pillars of the resource mobilisation strategies. Therefore, $\mathrm{H} 1$ is accepted, $\mathrm{H} 2$ is rejected, and $\mathrm{H} 3$ is partially accepted.

\section{Conclusion}

This research work analysed financial resource mobilisation strategies and sustainability within the context of 118 principal officers 50 NGOs in Minna, Niger State. The study findings have revealed that private contributions represent the major financial resource mobilisation strategy that NGOs in Minna employ to sustain themselves. It was determined that the government has not been supporting these NGOs with financing. Compared to studies in other areas, different forms of commercial activities were little used by NGOs as a financial mobilisation strategy. Hence, based on these findings, the study concludes that all three variables in the study are important but private contributions are the most crucial financial resource mobilisation strategy for enhancing sustainability of NGOs in Minna, Nigeria. The study suggested that management of NGOs should place more emphasis on private resource mobilisation strategies, especially through foundation grants, to improve their financial sustainability, and they also should limit overdependence on donor funds by focusing on establishing innovative income-generating activities and venturing into multiple sources of funding for their projects. This multiple approach would improve their financial sustainability.

Table 3. Collinearity Statistic Result

\begin{tabular}{lll}
\hline Variable & $\begin{array}{l}\text { Variance Inflation } \\
\text { Factor (VIF) }\end{array}$ & Tolerance Level \\
\hline Private contributions & 1.009 & .991 \\
Government funding & 1.004 & .996 \\
Commercial activities & 1.010 & .990 \\
Durbin-Watson $=1.360$ & & \\
\hline
\end{tabular}

Source: Authors' computation. 
Table 4. Result of Regression Analysis

\begin{tabular}{|c|c|c|}
\hline Model & $\begin{array}{c}\text { Standardised Coefficients } \\
\text { Beta }\end{array}$ & Sig \\
\hline (Constant) & & .000 \\
\hline Private contributions & $\begin{array}{c}.291 \\
(3.232)^{*}\end{array}$ & .002 \\
\hline Government funding & $\begin{array}{l}-.009 \\
(-.101)\end{array}$ & .920 \\
\hline Commercial activities & $\begin{array}{l}.041 \\
(.459)\end{array}$ & .647 \\
\hline
\end{tabular}

Dependent variable: sustainability

$\mathrm{R}=.291^{\mathrm{a}}, \mathrm{R}-$ Square $=.085, \mathrm{~F}=3.511, \mathrm{Sig} .=.018^{\mathrm{a}}$

Source: Authors' computation.

\section{Practical Implication}

The study established that private contributions represent the major financial resource mobilisation strategy for NGO sustainability in Nigeria. Commercial activities have not improved the financial strength of NGOs while government contributions have an inverse effect on the sustainability of NGOs in Nigeria. This implies that the government has not been supporting these NGOs with financing. The study advocates that to improve sustainability of NGOs in the country, the NGOs need to create more awareness about their operations to attract better contributions from private individuals and organisations; they should also develop good relationships with the donor agencies they engage with. These steps will encourage and inform donors that have partnered with the NGOs on how they can be reliable and effective players in the social mission. Also, NGOs should be more innovative by investing more in commercial activities that could enhance their survival.

\section{Limitation and Future Research Recommendations}

Academically, this study provided information on three financial resource mobilisation strategies and their impact on the sustainability of NGOs in Nigeria. However, there are some limitations embedded in this study. For example, the study is limited to Minna, Niger State, although it could be replicated in all states of the federation. Also, this study only focused on financial resource mobilisation strategies, whereas further studies could reveal more about the role of human and material resources, financial management, accountability, and transparency regarding the sustainability of NGOs.

\section{References}

Abdullahi, D., \& Baba, Y. T. (2016). Corporate funding and sustainability of non-governmental organizations in Africa. Games Review, 2(1), 17-37. Adeyeye, M. M. (2016). Non-governmental organisations and social entrepreneurship growth in Niger State of Nigeria. Journal of African Political Economy and Development, 1(1), 56-75.

Ali, A. A., \& Kilika, J. M. (2016). Effect of donor relation practices on financial sustainability of non-governmental organizations operating in Garissa County, Kenya. American Journal of Finance, 1(1), 40-55.

Arthur, B., \& Appiah-Kub, R. (2020). Performance improvement of non-governmental organisations through financial management: A case study of Young Men's Christian Association of Ghana. Retrieved February 25, 2011 from https://www.researchgate.net/publication/338763674_Performance_Improvement_of_Non-Governmental_Organisations_through_Financial_Management_A_Case_Study_of_ Young_Men\%27s_Christian_Association_of_Ghana

Bansal, P. (2001). Building competitive advantage and managing risk through sustainable development. Ivey Business Journal, 66: 47-52.

Batti, R. C. (2014). Challenges facing local NGOs in resource mobilization. Humanities and Social Sciences, 2(3), 57-64.

Benedict, A. \& Richard, A. (2020). Performance improvement of non-governmental organisations through financial management: a case study of young men's Christian association of Ghana. Journal of Accounting, Business and Finance Research, 8(2), 58-71.

Besel, K., Williams, C. L., \& Klak, J. (2011). Nonprofit sustainability during times of uncertainty. Nonprofit Management and Leadership, 22(1), 53-65.

Dimelu, M. U., Salua, E. S., \& Igbokwe, E. M. (2013). Performance of faith-based grassroot non-governmental organisations in rural development in Nasarawa State, Nigeria. International NGO journal, 8(7), 146-152. 
Di Zhang, D., \& Swanson, L. A. (2013). Social entrepreneurship in nonprofit organizations: An empirical investigation of the synergy between social and business objectives. Journal of Nonprofit \& Public Sector Marketing, 25(1), 105-125.

Gras, D., \& Mendoza-Abarca, K. I. (2014). Risky business? The survival implications of exploiting commercial opportunities by nonprofits. Journal of Business Venturing, 29(3), 392-404.

Hair Jr, J. F., Wolfinbarger, M., Money, A. H., Samouel, P., \& Page, M. J. (2015). Essentials of Business Research Methods, 28(1), 21-42.

Haywood, A. M., Hill, D. J., Dolan, A. M., Otto-Bliesner, B. L., Bragg, F., Chan, W. L., ... \& Zhang, Z. (2013). Large-scale features of Pliocene climate: results from the Pliocene Model Intercomparison Project. Climate of the Past, 9(1), 191-209.

Herzer, D., \& Nunnenkamp, P. (2013). Private donations, government grants, commercial activities and fundraising: Co-integration and causality for NGOs in international development cooperation. World Development, 46(1), 234-251.

Kangiri, H. (2015). Strategies for financial sustainability of civil society organizations: Case study of Nairobi County [Unpublished doctoral dissertation, United States International University-Africa].

Karanga, J. G., \& Karuti, J. K. (2014). Assessment of factors influencing financial sustainability of non-governmental organisations in Isiolo County, Kenya. International Journal of Economics, Commerce and Management, 2(9), 1-14.

Kearns, K. P., Bell, D., Deem, B., \& McShane, L. (2014). How nonprofit leaders evaluate funding sources: An exploratory study of nonprofit leaders. Nonprofit and Voluntary Sector Quarterly, 43(1), 121-143.

Kerlin, J. A., \& Pollak, T. H. (2011). Nonprofit commercial revenue: A replacement for declining government grants and private contributions? The American Review of Public Administration, 41(6), 686-704.

Khieng, S. (2014). Funding mobilization strategies of nongovernmental organisations in Cambodia. VOLUNTAS: International Journal of Voluntary and Nonprofit Organisations, 25(6), 1441-1464.

Khieng, S., \& Dahles, H. (2015). Commercialization in the non-profit sector: The emergence of social enterprise in Cambodia. Journal of Social Entrepreneurship, 6(2), 218-243.

Koech, J. D. (2017). Resource mobilization application for Non-Governmental Organisations in Kenya: case of health sector (Doctoral dissertation, Strathmore University).

Lewis, D. (2010). Nongovernmental organisations, definition and history. International Encyclopedia of Civil Society, 41(6), 1056-1062.

Liu, J., Yang, L., Wang, Z., \& Hahn, J. (2015). Winner takes all? The "blockbuster effect" in crowdfunding platforms. International Journal of Economics, Commerce and Management, 28(9), 1-14

Mbuya, J. G., \& Osodo, O. P. The influence of source of funding on the financial sustainability of non-governmental organizations in Uasin Gishu county, Kenya. International Journal of Non-Governmental Organizations, 3(1), 11-19.

Mitchell, G. E. (2014). Strategic responses to resource dependence among transnational NGOs registered in the United States. Voluntas: International Journal of Voluntary and Nonprofit Organisations, 25(1), 67-91.

Morris, M. H., Kuratko, D. F., \& Covin, J. G. (2012). Corporate entrepreneurship and innovation. (3rd ed.) Cengage/South-Western Publishers.

Ngeh, D. B. (2013). Non-governmental organisations (NGOs) and rural development in Nigeria. Mediterranean Journal of Social Sciences, 4(5), $107-112$.

Odunola, O. O., \& Odunsi, O. (2017). Contributions of community based organisations to poverty alleviation in Oyo State, Nigeria. Economic and Environmental Studies, 17(42), 185-203.

Shava, E. (2019). Accountability of non-governmental organisations in poverty alleviation programmes. Africa Insight, 49(1), $122-136$.

Spooner, C., \& Dadich, A. (2010). Issues for sustainability of non-government organizations in the alcohol and other drugs sector. Drug and Alcohol Review, 29(1), 47-52.

Stremfelj, L. R., Žnidarši, J., \& Mari, M. (2020). Government-funded sustainable development and professionalisation of NGOs. Sustainability, 12(18),1-16; https://doi.org/10.3390/su12187363

Svidroňová, M. (2014). Tax laws affecting the sustainability of NGOs in Slovakia. Sborník medzinárodního vědeckého semináře: Current trends in public sector research XVIII. Brno: Ekonomicko-správní fakulta, Masarykova univerzita, Pp 344-353.

Unerman, J., \& O'Dwyer, B. (2010). NGO accountability and sustainability issues in the changing global environment. Public Management Review, 12(4), 475-486.

Utuk, I. O. (2014). The role of non-governmental organizations (NGOs) in participatory and sustainable rural economic development in Nigeria. IOSR Journal of Economics and Finance, 4(1), 22-30.

Vaceková, G., \& Svidroňová, M. (2014). Benefits and risks of self-financing of NGOS:

Empirical evidence from the Czech Republic, Slovakia and Austria. E a M: Ekonomie a Management, 17(2). http://dx.doi.org/10.15240/ tul/001/2014-2-009

Valentinov, V., \& Vaceková, G. (2015). Sustainability of rural nonprofit organisations: Czech Republic and beyond. Sustainability, 7(8), 9890-9906. 